\title{
Corrosion of Snails (Gastropods) in Acidic Environment and Their Protection
}

\author{
Rajesh Kumar Singh ${ }^{1}$, Veena Kumari², Deepmala ${ }^{1}$ \\ ${ }^{1}$ Department of Chemistry, Jagdam College, Jai Prakash University, Chhapra, India \\ ${ }^{2}$ Department of Zoology, Deoghar College, Deoghar, India \\ Email: rks_jpujc@yahoo.co.in
}

How to cite this paper: Singh, R.K., Kumari, V. and Deepmala (2019) Corrosion of Snails (Gastropods) in Acidic Environment and Their Protection. Journal of Surface Engineered Materials and Advanced Technology, 9, 1-10.

https://doi.org/10.4236/jsemat.2019.91001

Received: November 26, 2018

Accepted: January 28, 2019

Published: January 31, 2019

Copyright $\odot 2019$ by author(s) and Scientific Research Publishing Inc. This work is licensed under the Creative Commons Attribution International License (CC BY 4.0).

http://creativecommons.org/licenses/by/4.0/

\begin{abstract}
Snails' protection is essential because this species is to maintain a balanced ecology of water sources. They occur in rivers as well as ponds and balance the $\mathrm{pH}$ level of water. But these sources of water are contaminated by effluents, pollutants, acid rain, particulates, biological wastes etc. They can change the $\mathrm{pH}$ of water. Water is absorber of carbon dioxide and it converts carbon dioxide into carbonic. Other above mentioned wastes also increase the concentration of $\mathrm{H}^{+}$ions in water. They produce hostile environment for snails. The outer part of snails is made of $\mathrm{CaCO}_{3}$. It produces chemical reaction in acidic medium and corrosion reaction is accelerated, and thus deterioration starts on the surface of snails. This medium makes their survival become miserable. For this work, corrosion of the snails' study in the $\mathrm{pH}$ values of water is 6.5 in $\mathrm{H}_{2} \mathrm{CO}_{3}$ environment. The corrosion rates of snails were calculated by gravimetric methods and potentiostat technique. Aloe Vera was used for corrosion protection in acidic medium. The surface adsorption phenomenon was studied by Langmuir isotherm. Aloe Vera formed thin surface film on the interface of snails which adhered with chemical bonding. It was confirmed by activation energy, heat of adsorption, free energy, enthalpy and entropy. The results of surface coverage area and inhibitors efficiency indicated that Aloe Vera developed a strong protective barrier in the acidic medium.
\end{abstract}

\section{Keywords}

Corrosion, Snails, Aloe Vera, Carbonic Acid, Potentiostat, Thin Film Formation

\section{Introduction}

The living animals' outer parts are made of calciferous metals to corrode in the acidic medium. Corrosion occurs in living organisms [1]. The animals' outer 
layer is created by calcium carbonate [2] to corrode in acidic environment. Corrosive substances interact with living organism [3] to produce corrosion cell which is exhibited autoredox with snails [4] and to disintegrate their outer layers. It observes that carbon dioxide [5] reacts with water to form carbon which produces a hostile environment [6] for snails and mollusca [7]. Ocean water [8] is a major absorber of carbon dioxide to change $\mathrm{pH}$. Carbonic acid interacts with snails to exhibit chemical and thus calcification [9] starts on their surface. The oxides of sulphur [10] dissolve in water to produce sulphrous and sulphuric acid. These acids produce corroding [11] effects with snails. Oxides of nitrogen [12] absorb water to form nitrous and nitric acids and they generate corrosive environment for molluscs. Acid rain [13] can change $\mathrm{pH}$ of water and produce acidic medium for snails. Industrial wastes and human wastes contaminate water sources and alter the $\mathrm{pH}$ values of water in this way it makes water corrosive for snails and molluscs. The temperature [14] of the earth is increasing due to global warming and thus water sources temperature is also increased and snails [15] undergo corrosion reaction. Various types of techniques use for corrosion protection [16] like anodic and cathodic protection, galvanization and electroplating, dipping, anodization, spray, nanocoating and inhibitors action. Aloe Vera is used for skin corrosion protection in acidic environment. Snails' corrosion [17] [18] can be control by inhibitor action of Aloe Vera in the above mentioned environment. Aloe Vera forms a thin barrier [19] [20] on the surface of snails and it is confirmed by activation energy, heat of adsorption, free energy, enthalpy and entropy and these thermal parameters [21] results are noticed that Aloe Vera has good inhibition properties in acidic medium. It forms complex barriers on the surface of snails.

\section{Experimental}

Snails dipped into carbonic acid solution which $\mathrm{pH}$ value was 6.2. The corrosion rates of snails were determined by gravimetric method at mentioned periods 1 , 2, 3, 4 and 5 years at $288^{\circ} \mathrm{K}, 298^{\circ} \mathrm{K}, 303^{\circ} \mathrm{K}, 308^{\circ} \mathrm{K}$ and $313^{\circ} \mathrm{K}$ temperatures without use of Aloe Vera. Aloe Vera was used as inhibitor in carbonic acid medium and the calculated of corrosion rate of snails above mentioned years and temperatures at 50,60, 70, 80 and $90 \mathrm{M}$ concentrations. Potentiostat 324 model used to determine the corrosion potential, corrosion current density at different temperatures and concentrations. These results were obtained by application of calomel electrode as auxiliary electrode and Pt reference electrode. The snail kept between these electrode and external current passed through without and with inhibitor. The results were noticed that anodic current decreased and cathodic current increased by the use of Aloe Vera. The gravimetric method corrosion rate results were approximated to potentiostat corrosion obtained results.

\section{Results and Discussion}

The corrosion rate of snails were determined by without and with Aloe Vera in 
mpy (miles per year) at different temperatures, concentrations and times in years by the use of formula $\mathrm{K}=534 \times \Delta \mathrm{W} / \mathrm{DAt}$ (where $\Delta \mathrm{W}$ is weight loss in $\mathrm{g}, \mathrm{A}$ is area in sq inch, $\mathrm{t}$ is immersion time in year). The dipping times were $1,2,3,4$ and 5 years and temperatures are $288^{\circ} \mathrm{K}, 298^{\circ} \mathrm{K}, 303^{\circ} \mathrm{K}, 308^{\circ} \mathrm{K}$ and $313^{\circ} \mathrm{K}$ without inhibitors corrosion rate of snail is calculated and their values were recorded in Table 1 . The addition of Aloe Vera in carbonic acid medium and corrosion rate of snail calculated at $288^{\circ} \mathrm{K}, 298^{\circ} \mathrm{K}, 303^{\circ} \mathrm{K}, 308^{\circ} \mathrm{K}$ and $313^{\circ} \mathrm{K}$ temperatures and 50,60,70, 80 and $90 \mathrm{M}$ concentrations and its values were mentioned in Table 1. It observed that without action of inhibitor corrosion rate of snail increased as duration of times and temperatures were increased and but it values were decreased after addition of Aloe Vera such types of trends noticed in Figure $1 \mathrm{~K} \cdot \mathrm{Vs} \cdot \mathrm{t}$, Figure $2 \mathrm{~K}$ Vs T and Figure $3 \mathrm{~K}$ Vs C.

The surface coverage area and inhibitor efficiency were calculated by formula $\theta=(1-\mathrm{K} / \mathrm{Ko})$ and $\% \mathrm{IE}=(1-\mathrm{K} / \mathrm{Ko}) \times 100$ (where Ko corrosion rate without inhibitor and $\mathrm{K}$ corrosion rate with inhibitor) and their values were given in $\mathrm{Ta}$ ble 2 . The surface coverage area and inhibitor efficiency were calculated by formula $\theta=(1-\mathrm{K} / \mathrm{Ko})$ and their values were given in Table 2 . The results of Table 2 were shown that surface coverage area and percentage inhibitors efficiency were enhanced when inhibitors added at different temperatures and concentrations as per year. Such types of trends were noticed in Figure $4 \theta \mathrm{Vs} \mathrm{T}$ and Figure $5 \theta$ Vs C.

The percentage inhibitors of Aloe Vera at different temperatures and concentrations as one year interval were calculated by $\% \mathrm{IE}=(1-\mathrm{K} / \mathrm{Ko}) \times 100$ (where Ko corrosion rate without inhibitor and $\mathrm{K}$ corrosion rate with inhibitor) and the values were written in Table 3 . The results of Table 3 were depicted that percentage inhibitors efficiency were increased as temperatures and concentration were enhanced. Such types of trends also observed in Figure 6 \%IE Vs T and Figure 7 \%IE Vs C.

Surface adsorption phenomenon was studied by activation energy, heat of adsorption, free energy, enthalpy and entropy. Activation energy was determined by formula $\mathrm{K}=\mathrm{Ae}^{-\mathrm{Ea} / \mathrm{RT}}$ (where $\mathrm{K}$ is corrosion rate, $\mathrm{Ea}$ is activation energy and $\mathrm{T}$ is absolute temperature without and with action of Aloe Vera at different temperatures and concentrations and their values were recorded in Table 4. It observed that activation energy increased without inhibitors but its values decreased after addition of inhibitors. These results were shown in Table 4 which

Table 1. Corrosion rate of snail absence and presence of Aloe Vera in $\mathrm{H}_{2} \mathrm{CO}_{3}$.

\begin{tabular}{cccccccccc}
\hline $\mathrm{t}(\mathrm{yrs})$ & $\mathrm{Ko}(\mathrm{mpy})$ & $\operatorname{logKo}$ & $\mathrm{K}(\mathrm{mpy})$ & $\operatorname{logK}$ & $\log (\theta / 1 \theta)$ & $\mathrm{C}(\mathrm{M})$ & $\log \mathrm{C}$ & $\mathrm{T}\left({ }^{\circ} \mathrm{K}\right)$ & $(1000 \times 1 / \mathrm{T})$ \\
\hline 1 & 99.663 & 1.998 & 29.134 & 1.464 & 0.383 & 50 & -1.30 & 288 & 3.47 \\
2 & 134.549 & 2.128 & 33.123 & 1.520 & 0.486 & 60 & -1.22 & 298 & 3.35 \\
3 & 148.865 & 2.172 & 42.484 & 1.628 & 0.398 & 70 & -1.15 & 303 & 3.30 \\
4 & 176.698 & 2.247 & 56.212 & 1.479 & 0.331 & 80 & -1.09 & 308 & 3.24 \\
5 & 187.353 & 2.272 & 61.712 & 1.790 & 0.308 & 90 & -1.04 & 313 & 3.19 \\
\hline
\end{tabular}




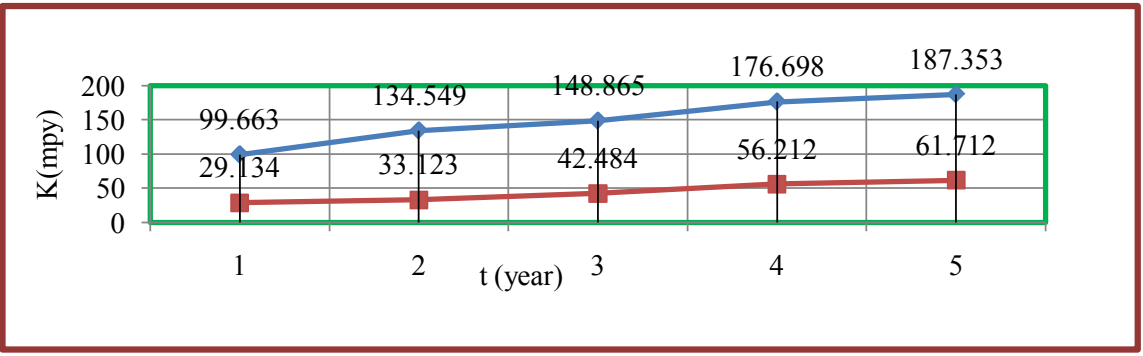

Figure 1. K Vs t for snails at different years.

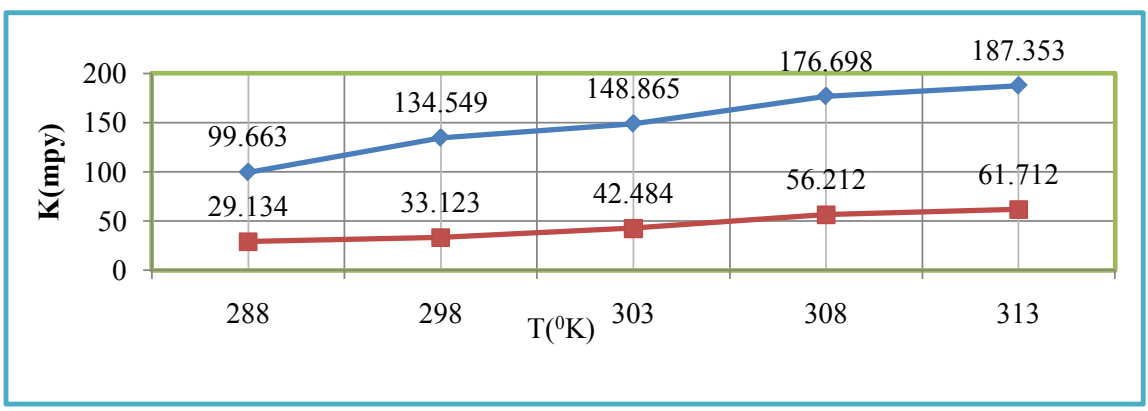

Figure 2. K Vs T for snails at different temperatures.

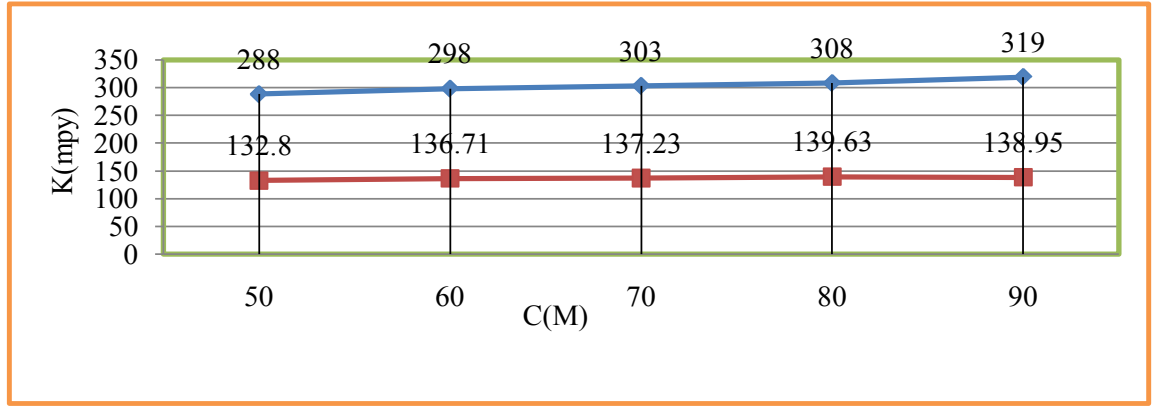

Figure 3. K Vs C for snails at concentrations.

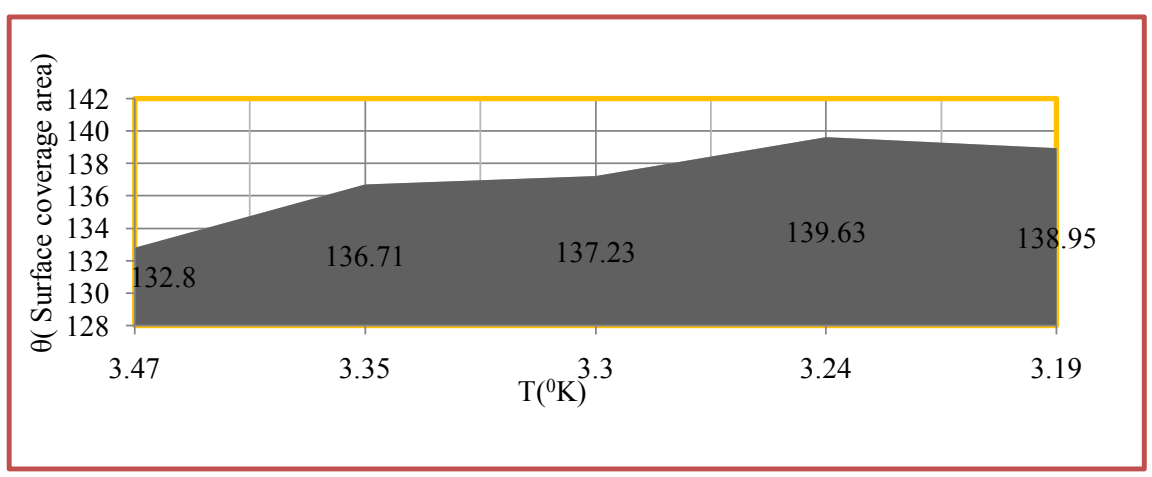

Figure 4. $\theta$ Vs T for snails in Aloe Vera.

indicated that inhibitors adhered on snails by chemical bonding and their values were obtained by Figure 8 plotted $\operatorname{logK}$ Vs 1/T.

Heat of adsorption values were found to be negative which indicated that Aloe Vera was shown an exothermic reaction in $\mathrm{H}_{2} \mathrm{CO}_{3}$ medium. It adsorbed on the 
Table 2. Surface coverage areas developed by Aloe Vera on the snails in $\mathrm{H}_{2} \mathrm{CO}_{3}$.

\begin{tabular}{cccccccc}
\hline Ко & $\mathrm{K}$ & $\mathrm{K} / \mathrm{Ko}$ & $\theta=(1-\mathrm{K} / \mathrm{Ko})$ & $\mathrm{T}(\mathrm{y})$ & $\mathrm{C}(\mathrm{M})$ & $\mathrm{T}\left({ }^{\circ} \mathrm{K}\right)$ & $(1000 \times 1 / \mathrm{T})$ \\
\hline 99.663 & 29.134 & 0.29233 & 0.7076 & 1 & 50 & 288 & 3.47 \\
134.549 & 33.123 & 0.24617 & 0.7538 & 2 & 60 & 298 & 3.35 \\
148.865 & 42.484 & 0.28539 & 0.7146 & 3 & 70 & 303 & 3.30 \\
176.698 & 56.212 & 0.31812 & 0.6818 & 4 & 80 & 308 & 3.24 \\
187.353 & 61.712 & 0.32939 & 0.6706 & 5 & 90 & 313 & 3.19 \\
\hline
\end{tabular}

Table 3. \% Inhibition efficiency developed by Aloe Vera in $\mathrm{H}_{2} \mathrm{CO}_{3}$.

\begin{tabular}{ccccccccccc}
\hline Ko & $\mathrm{K}$ & $\mathrm{K} / \mathrm{Ko}$ & $\theta$ & $\begin{array}{c}\% \mathrm{IH}= \\
(\theta \times 100)\end{array}$ & $\log (\theta / 1 \theta)$ & $\mathrm{T}(\mathrm{y})$ & $\mathrm{C}(\mathrm{mM})$ & $\log \mathrm{C}$ & $\mathrm{T}\left({ }^{\circ} \mathrm{K}\right)$ & $(1000 \times 1 / \mathrm{T})$ \\
\hline 99.663 & 29.134 & 0.29233 & 0.7076 & 70.76 & 0.383 & 1 & 50 & -1.30 & 288 & 3.47 \\
134.541 & 33.123 & 0.24617 & 0.7538 & 75.38 & 0.486 & 2 & 60 & -1.22 & 298 & 3.35 \\
148.865 & 42.484 & 0.28539 & 0.7146 & 71.46 & 0.398 & 3 & 70 & -1.15 & 303 & 3.30 \\
176.698 & 56.212 & 0.31812 & 0.6818 & 68.18 & 0.331 & 4 & 80 & -1.09 & 308 & 3.24 \\
187.353 & 61.712 & 0.32939 & 0.6706 & 67.06 & 0.308 & 5 & 90 & -1.04 & 313 & 3.19 \\
\hline
\end{tabular}

Table 4. Thermal parameters of Aloe Vera with snails.

\begin{tabular}{cccccc}
\hline $\mathrm{T}\left({ }^{\circ} \mathrm{K}\right)$ & 288 & 298 & 303 & 308 & 313 \\
\hline $\mathrm{C}(\mathrm{M})$ & 50 & 60 & 70 & 80 & 90 \\
Eao & 132.80 & 136.71 & 137.23 & 139.63 & 138.950 \\
$\mathrm{Ea}$ & 97.311 & 97.624 & 102.841 & 108.728 & 109.469 \\
$\mathrm{q}$ & -25.313 & -31.212 & -25.177 & -20.575 & -18.278 \\
$\Delta \mathrm{G}$ & -198.48 & -195.398 & -199.002 & -203.327 & -202.557 \\
$\Delta \mathrm{H}$ & -148.348 & -187.837 & -273.381 & -410.333 & -475.361 \\
$\Delta \mathrm{S}$ & -99.886 & -114.204 & -143.132 & -189.007 & -212.188 \\
\hline
\end{tabular}

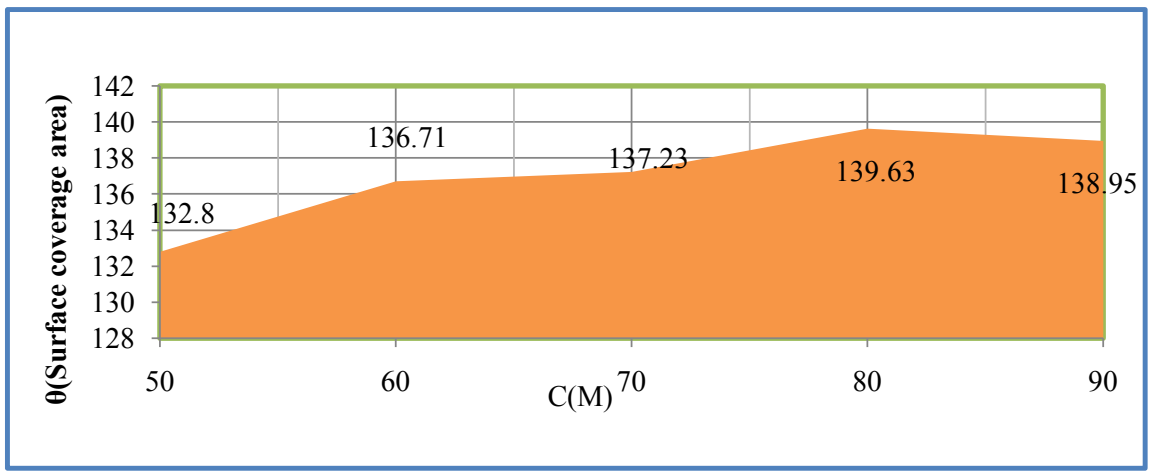

Figure 5. $\theta$ Vs $\mathrm{C}$ for snails in Aloe Vera.

surface of snails by chemical bonding. The values of heat of adsorption were determined by Langmuir isotherm $\log (\theta / 1-\theta)=\log \mathrm{A}+\log \mathrm{C}-\mathrm{q} / 2.303 \mathrm{RT}$ and Figure 9 plotted $\log (\theta / 1-\theta) \mathrm{Vs} 1 / \mathrm{T}$ and Figure 10 plotted against $\log (\theta / 1-\theta)$ Vs $\log C$ and their values were recorded in Table 4. 


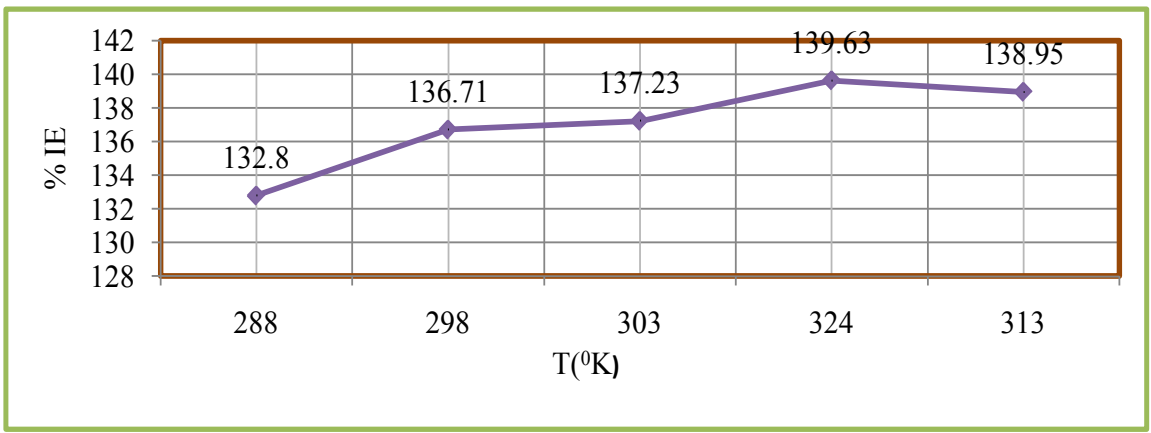

Figure 6. \%IE Vs T for snails in Aloe Vera.

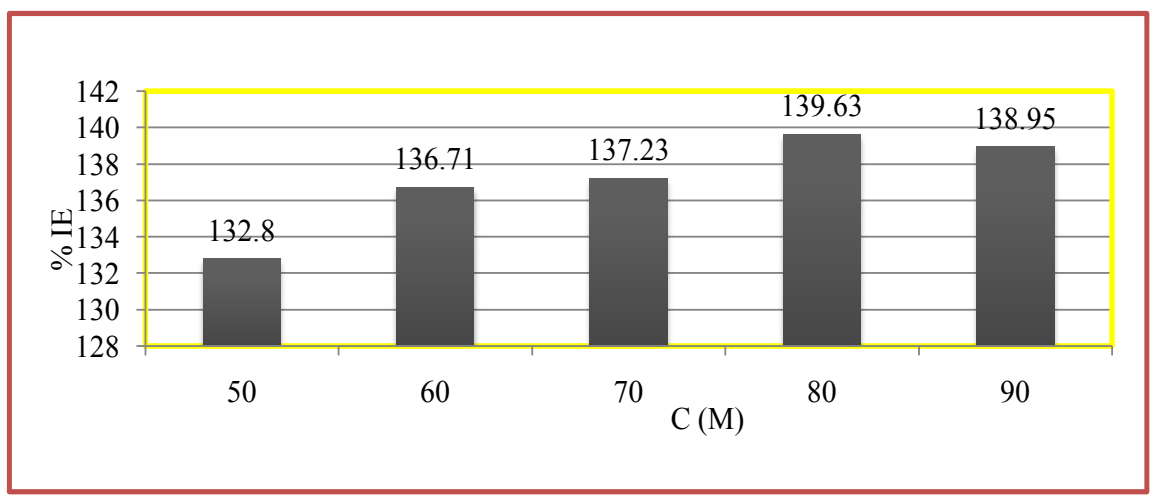

Figure 7. \%IE Vs C for snails in Aloe Vera.

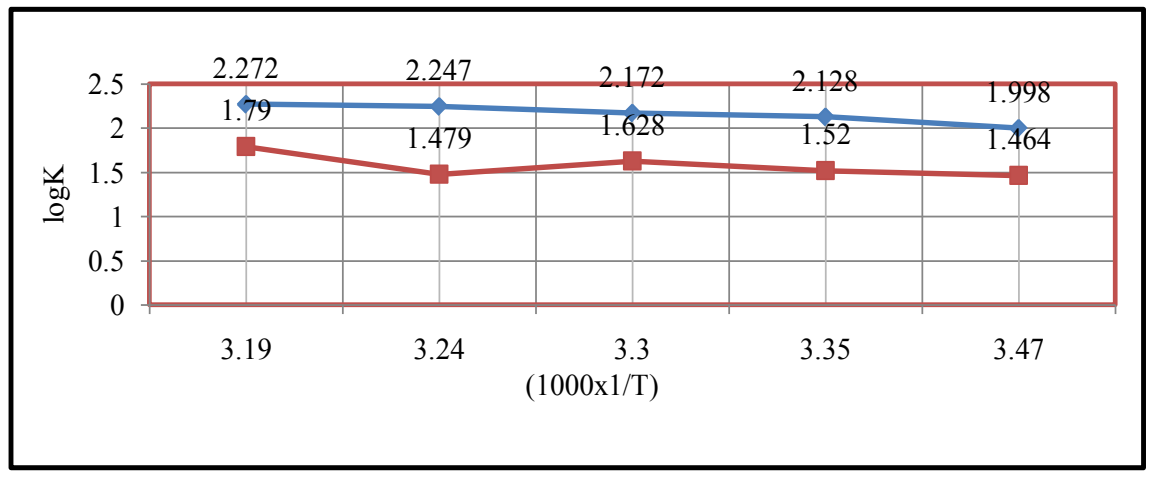

Figure 8. $\log \mathrm{K}$ Vs $1 / \mathrm{T}$ for snails in Aloe Vera.

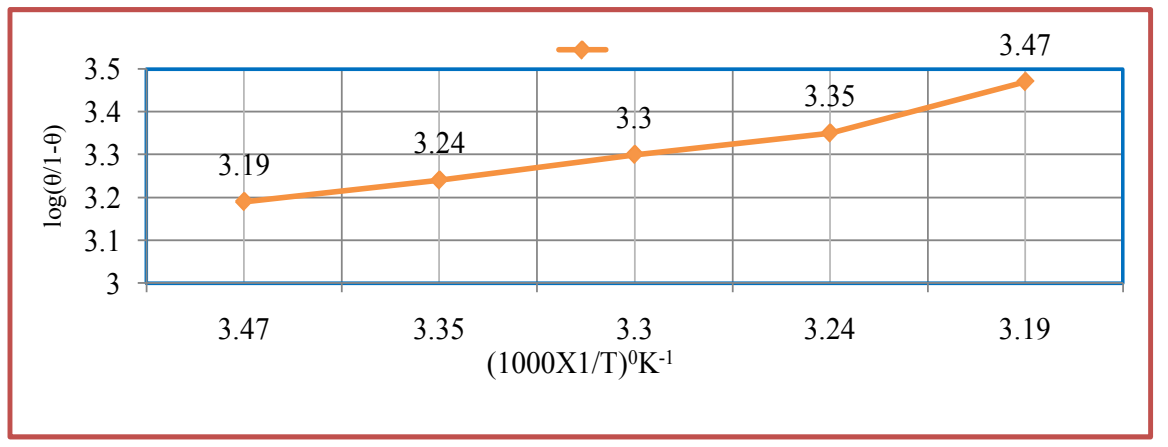

Figure 9. $\log (\theta / 1-\theta)$ Vs $1 /$ T for snails in Aloe Vera. 


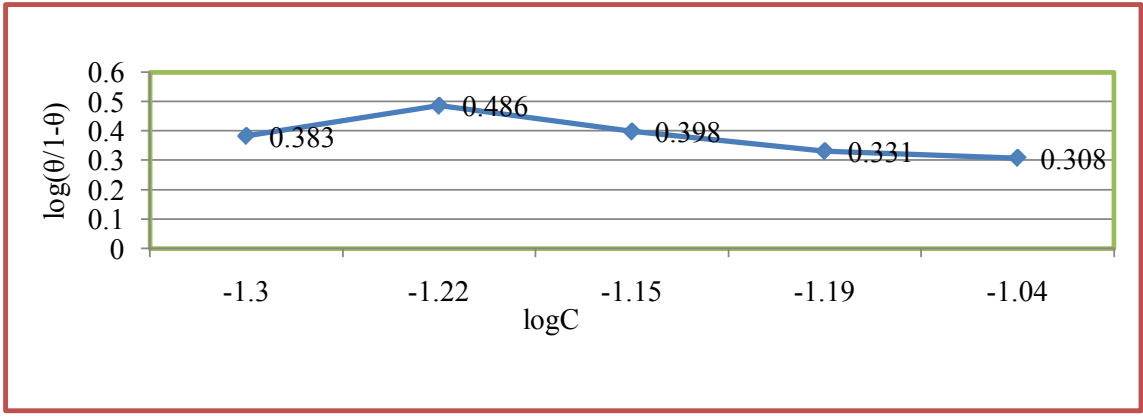

Figure $10 . \log (\theta / 1-\theta)$ Vs $\log C$ for snails in Aloe Vera.

Free energy of inhibitor Aloe Vera was calculated by equation $\Delta \mathrm{G}=2.303$ $\log (33.3 \mathrm{~K})$ and their values were given in Table 4 . Their values noticed that inhibitor action a chemical reaction because free energy values were negative and their values mentioned in Table 4.

Enthalpy of used inhibitors was determined by transition state equation $\mathrm{K}=$ $\mathrm{RT} / \mathrm{Nhe}^{\Delta / \mathrm{R}} \mathrm{e}-\Delta \mathrm{H} / \mathrm{RT}$ and its values were recorded in Table 4. These values indicated that inhibitor's Aloe Vera boned with snail by chemical bonding.

Entropy of Aloe Vera was determined by equation by $\Delta \mathrm{G}=\Delta \mathrm{H}-\mathrm{T} \Delta \mathrm{S}$ and their values were mentioned in Table 4. Their values were shown that deposition of Aloe Vera on the surface of snail was an exothermic process. It formed stable barrier on the surface of snail. All five values of thermal parameters plotted against $\mathrm{T}$ in Figure 11 and Figure 12 against $\mathrm{C}$.

The corrosion potential, corrosion current density and corrosion rate were determined by the equation $\Delta \mathrm{E} / \mathrm{I}=1 / 2.303 \beta \mathrm{a} \beta \mathrm{c} /(\beta \mathrm{a}+\beta \mathrm{c})$ and $\mathrm{C} \mathrm{R}(\mathrm{mpy})=$ $0.1288 \mathrm{Ic}\left(\mathrm{mA} / \mathrm{cm}^{2}\right) \mathrm{XE} / \rho$ and values were recorded in Table 5. It observed that without inhibitor corrosion potential and corrosion current were decreased but after addition of Aloe Vera corrosion current densities were increased. It also reduced the corrosion potential and corrosion current. The corrosion rate calculated by potentiostat technique and their values were tallied with the corrosion rate determined by gravimetric method. Corrosion potential versus corrosion current density was plotted in Figure 13. This plot indicated that anodic current reduced as addition of inhibitor but cathodic current enhanced.

\section{Conclusion}

Snails' corrosion occurs due to the change of the $\mathrm{pH}$ of water. Water $\mathrm{pH}$ is altered by contamination effluents, industrial polluters, and various types of wastes and acid rains. Snails' outer layers are constructed by calcium carbonate. In the acidic medium, calcification starts on their surface by the chemical process. It produces pitting, stress and crevice corrosion. For the protection of such types of corrosion, Aloe Vera is used as an inhibitor. Aloe Vera forms thin films on the surface of snails. The thin film formation is confirmed by thermal parameters like activation energy, heat of adsorption, free energy, enthalpy and entropy. Aloe Vera' surface adsorption phenomenon on snails is also satisfied by 


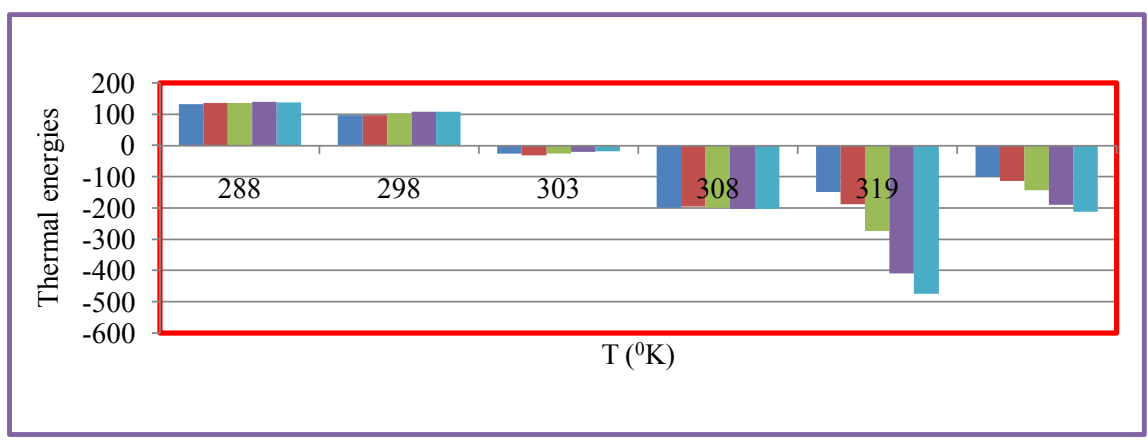

Figure 11. Thermal energies Vs T for Aloe Vera with snails.

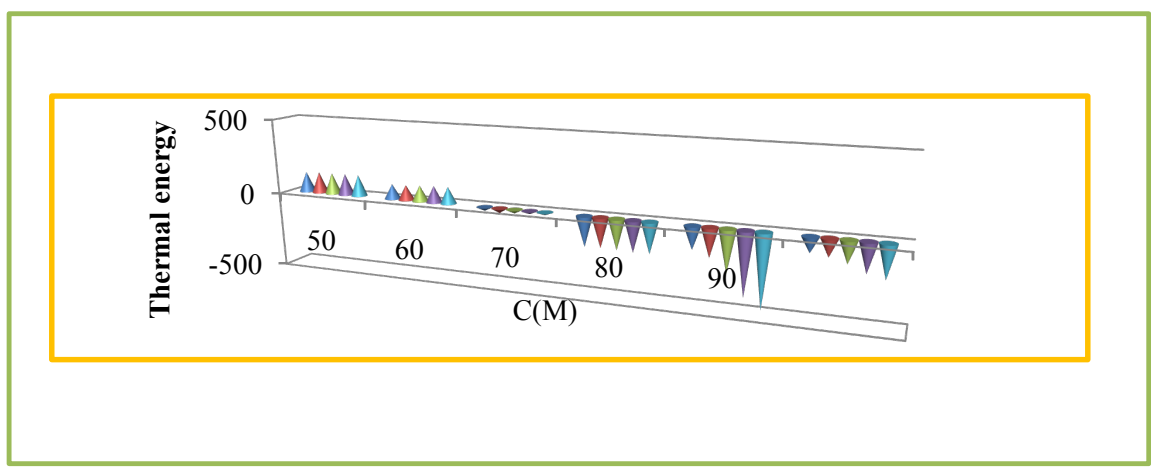

Figure 12. Thermal energies Vs C for Aloe Vera with snails.

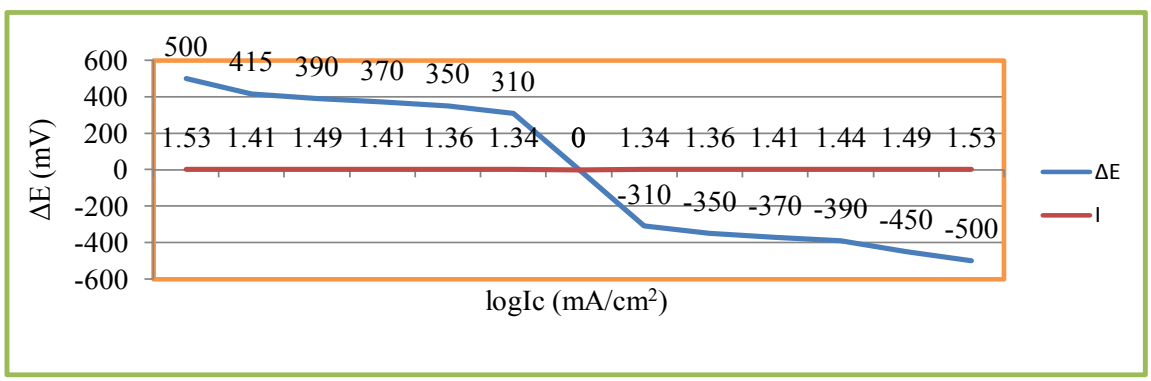

Figure 13. $\Delta \mathrm{E}$ Vs Ic for snails with Aloe Vera.

Table 5. Potentiostatic results of snails in $\mathrm{H}_{2} \mathrm{CO}_{3}$ medium in presence of Aloe Vera.

\begin{tabular}{ccccccccc}
\hline $\mathrm{IH}$ & $\Delta \mathrm{E}(\mathrm{mV})$ & $\mathrm{I}(\mathrm{mA})$ & $\mathrm{Ba}(\mathrm{mV})$ & $\mathrm{Bc}(\mathrm{mV})$ & $\mathrm{Ic}(\mathrm{mA})$ & $\log _{\mathrm{C}}$ & $\mathrm{C}(\mathrm{mM})$ & $\mathrm{K}(\mathrm{mpy})$ \\
\hline $\mathrm{IH}(0)$ & -500 & 450 & 260 & 130 & 34 & 1.53 & 00 & 208 \\
$\mathrm{~K}(50)$ & -415 & 371 & 188 & 165 & 31 & 1.49 & 50 & 190 \\
$\mathrm{~K}(60)$ & -390 & 320 & 140 & 185 & 28 & 1.44 & 60 & 171 \\
$\mathrm{~K}(70)$ & -370 & 290 & 130 & 190 & 26 & 1.41 & 70 & 159 \\
$\mathrm{~K}(80)$ & -350 & 270 & 110 & 195 & 23 & 1.36 & 80 & 141 \\
$\mathrm{~K}(90)$ & -310 & 250 & 95 & 200 & 22 & 1.34 & 90 & 135 \\
\hline
\end{tabular}

Langmuir isotherm. Aloe Vera reduces the concentration of $\mathrm{H}^{+}$ions and enhances the concentration of oxygen molecules. It is nitrogen containing rich or- 
ganic compounds which capture $\mathrm{H}^{+}$ions and less $\mathrm{H}_{2}$ gas is released and thus corroding effects of snails are suppressed.

\section{Acknowledgements}

The authors are thankful for UGC-New Delhi, India for providing financial support for this work. I also thank my research team for their collection of data and graph plotting. I am very grateful professor G. Udhayabhanu IITD and professor Sanjoy Misra providing laboratory facility.

\section{Conflicts of Interest}

The authors declare no conflicts of interest regarding the publication of this paper.

\section{References}

[1] Doney, S.C. (2006) The Dangers of Ocean Acidification. Scientific American, 294, 58-65. https://doi.org/10.1038/scientificamerican0306-58

[2] Caldeira, K. and Wickett, M.E. (2005) Ocean Model Predictions of Chemistry Change from Carbon Dioxide Emissions to the Atmosphere and Ocean. Journal of Geophysical Research (Oceans), 110, C09S04. https://doi.org/10.1029/2004JC002671

[3] De'ath, G., Lough, J.M., et al. (2009) Declining Coral Calcification on the Great Barrier Reef. Science, 323, 116-119. https://doi.org/10.1126/science.1165283

[4] Doney, S.C., Fabry, V.J., et al. (2009) Ocean Acidification: The Other $\mathrm{CO}_{2}$ Problem. Annual Review of Marine Sciences, 1, 169-192. https://doi.org/10.1146/annurev.marine.010908.163834

[5] Fabry, V.J. (2008) Ocean Science-Marine calcifiers in a High- $\mathrm{CO}_{2}$ Ocean. Science, 320, 1020-1022. https://doi.org/10.1126/science.1157130

[6] Fabry, R.A., Sabine, C.L., et al. (2008) Evidence for Upwelling of Corrosive Water onto the Continental Shelf. Science, 320, 1490-1492.

https://doi.org/10.1126/science.1155676

[7] Moy, A.D., Howard, W.R., et al. (2009) Reduced Calcification in Modern Southern Ocean Planktonic Foraminifera. Nature Geoscience, 2, 276-280. https://doi.org/10.1038/ngeo460

[8] Orr, J.C., Fabry, V.J., et al. (2005) Anthropogenic Ocean Acidificiation over the Twenty-First Century and Its Impact on Calcifying Organisms. Nature, 437, 681-686. https://doi.org/10.1038/nature04095

[9] Sabine, C.L., Feely, R.A., et al. (2004) The Oceans Sink for Anthropogenic $\mathrm{CO}_{2}$. Science, 305, 367-371. https://doi.org/10.1126/science.1097403

[10] Silveman, J., Lazar, B., et al. (2009) Coral Reefs May Start Dissolving When Atmospheric $\mathrm{CO}_{2}$ Doubles. Geophysical Research Letters, 2, 36-43.

[11] Steinacher, M., Joos, F., Frölicher, T.L., Plattner, G.-K. and Doney, S.C. (2009) Imminent Ocean Acidification in the Arctic Projected with the NCAR Global Coupled Carbon Cycle-Climate Model. Biogeosciences, 6, 515-533. https://doi.org/10.5194/bg-6-515-2009

[12] Wootton, J.T., Pfister, C.A. and Forester, J.D. (2008) Dynamic Patterns and Ecological Impacts of Declining Ocean $\mathrm{pH}$ in a High-Resolution Muti-Year Dataset. Pro- 
ceeding of the National Academy of Sciences of the United States of America, 105, 18848-18853. https://doi.org/10.1073/pnas.0810079105

[13] Caldeira, K. and Wickett, M.E. (2003) Anthropogenic Carbon and Ocean pH. Nature, 425, 365. https://doi.org/10.1038/425365a

[14] Fabry, V.J. (1990) Shell Growth Rates of Pteropod and Heteropd Mollusks and Aragonite Production in the Open Ocean: Implications for the Marine Carbonate System. Journal of Marine Research, 48, 209-222. https://doi.org/10.1357/002224090784984614

[15] Gattuso, J.P., Frankignoulle, I.M., et al. (1998) Effect of Calcium Carbonate Saturation of Seawater on Coral Calcification. Global and Planetary, 18, 37-46. https://doi.org/10.1016/S0921-8181(98)00035-6

[16] Kleypas, J.A., et al. (1999) Geochemical Consequences of Increased Atmospheric $\mathrm{CO}_{2}$ on Coral Reefs. Science, 284, 118-200. https://doi.org/10.1126/science.284.5411.118

[17] Kolbert, E. (2006) The Darkening Sea: Carbon Emissions and the Ocean. The New Yorker, 20 November 2006, 66-75.

[18] Riebesell, U. (2004) Effect of $\mathrm{CO}_{2}$ Enrichment on Marine Phytoplankton. Journal of Oceanography, 60, 719-729. https://doi.org/10.1007/s10872-004-5764-z

[19] Riebesell, U.I. and Morel, F.M. (2000) Reduced Calcification of Marine Plankton in Response to Increased Atmosphere $\mathrm{CO}_{2}$. Nature, 407, 364-367. https://doi.org/10.1038/35030078

[20] Ruttiman, J. (2006) Sick Seas. Nature, 442, 978-980. https://doi.org/10.1038/442978a

[21] Singh, R.K. (2015) Aloe Vera Used for the Protection of Earthworm. Agricultural and Biological Sciences Journal, 1, 10-15. 